УДК 377.352

Тетяна СТОЙЧИК, кандидат педагогічних наук, заступник директора з навчально-виробничої роботи Криворізького професійного гірничо-технологічного лічею

\title{
УМОВИ ФОРМУВАННЯ СОЦІАЛЬНОГО ПАРТНЕРСТВА В ЗАКЛАДАХ ПРОФЕСІЙНОЇ (ПРОФЕСІЙНО-ТЕХНІЧНОЇ) ОСВІТИ В УКРАЇНI
}

\author{
Tetyana STOYCHYK, PhD in Pedagogy, Kryvyi Rih \\ Professional Mining-Technological Lyceum Vice-Director of \\ Training and Manufacturing Activity
}

\section{CONDITIONS FOR THE FORMATION OF SOCIAL PARTNERSHIP IN THE INSTITUTIONS OF VOCATIONAL EDUCATION IN UKRAINE}

\begin{abstract}
У статті визначені основні суб'єкти соціального партнерства, розглянуті передумови його ефективного функціонування. Автор виділяє основні та додаткові умови формування і забезпечення таких основних характеристик ефективного соціального партнерства, як: забезпечення високої якості підготовки фахівців за професією, спеціальністю; запровадження нових професій, спеціальностей за запитом суспільства; контрактна форма реалізації партнерських взаємин; удосконалення процедури проходження виробничої та переддипломної практики здобувачів освіти, створення спільних інформаційних центрів, інформатизація економіки. Обгрунтовується основа для подальших наукових досліджень.
\end{abstract}

Ключові слова: професійна підготовка, здобувач освіти, фахівець, заклад професійної (професійно-технічної) освіти.

Key words: vocational training, applicant for education, specialist, institution of professional (vocational) education.

Мета: дослідити та обгрунтувати умови розвитку соціального партнерства в Україні.

Постановка проблеми в загальному викладі. У сучасному європейському співтоваристві соціальне партнерство розглядається як ефективний механізм функціонування та розвитку економіки. В Україні становлення і розвиток системи соціального партнерства відбувається одночасно з формуванням ринкової економіки, правової держави, грома-

(c) Т. Стойчик дянського суспільства та їх інститутів.

Аналіз досліджень і публікацій. Соціальне партнерство розглядається неоднозначно. На думку науковців В. Красномовець та А. Пасєки, це "необхідна умова соціально-економічного прогресу" [6]; Ю. Ситника - "форма регулювання соціально-правових відносин між соціальними суб'єктами через розроблення і реалізацію спільних соціально-трудових договорів, програм чи угод на визначені терміни" [10]; О. Грішнова - "система взаємозв'язків між найманими працівниками, трудовими колективами, професійними спілками, з одного боку, роботодавцями та їх об'єднаннями - 3 другого, і державою та органами місцевого самоврядування - 3 третього, їхніми представниками та спільно створеними органами з регулювання соціально-трудових відносин, які полягають у взаємних консультаціях та переговорах на взаємоузгоджених принципах для дотримання прав та інтересів працівників, роботодавців і держави" [1].

Тобто більшість вітчизняних науковців не розглядають соціальне партнерство як ефективний механізм розвитку й функціонування ринкової економіки, який потребує відповідного правового забезпечення та розвинутого громадянського суспільства, як основні умови його формування та ефективного використання. Хоча більшість 3 них погоджуються, що соціальне партнерство безпосередньо залежить від економічного та соціального добробуту держави і що "одним із суспільно значимих інститугів, який має сприяти розв'язанню гострих соціальних проблем, опрацюванню та реалізації сучасної соціальної політики, $\epsilon$ інститут соціального партнерства.

Виклад основного матеріалу дос- лідження. Сьогодні соціальне партнерство здійснюється на міжнародному (мегаекономічному), національному (макроекономічному), галузевому і регіональному (мезоекономічному), виробничому (мікроекономічному) рівнях. Головними його суб'єктами виступають наймані працівники, трудові колективи, професійні спілки - з одного боку; роботодавці та їх об'єднання - з другого; держава та органи місцевого самоврядування - 3 третього, а також їхні представники і спільно створені органи з регулювання соціально-трудових відносин. У більшості країн Європейського Союзу (далі $\mathrm{GC}$ ) - це організації та рухи громадянського суспільства [2].

Постійне представництво громадських організацій у тристоронніх органах соціального партнерства або безпосередньо, або через роботу в окремих комітетах передбачено в більшості європейських держав, наприклад, Мальті та Естонії; у Франції членами національного органу соціального партнерства $€$ представники об'єднань громадян - кооперативних організацій, організацій взаємодопомоги, сімейних асоціацій [4].

Тому вважаємо, що однією з умов розвитку соціального партнерства в Україні має стати становлення та розвиток громадянського суспільства і його інститутів - громадських організацій, рухів, профспілкових об'єднань, політичних партій тощо.

На міжнародному (мегаекономічному) рівні суб'єктами соціального партнерства виступають окремі держави та міжнародні організації.

Як правило, ефективне соціальне партнерство характеризується:

- високою якістю підготовки фахівців за профілем спеціальності; 
- системним запровадженням нових спеціальностей за запитом суспільства;

- застосуванням контрактних форм реалізації партнерських взаємин, фінансуванням підприємцями матеріальнотехнічної бази закладів освіти;

- постійним удосконаленням процедури проходження виробничої та переддипломної практики здобувачами освіти на підприємствах, в організаціях, які надають місця для проходження практики, підготовки дипломів і курсових робіт, затверджують іменні стипендії, беруть участь у формуванні піклувальних фондів, в оцінці якості знань випускників тощо;

- створенням спільно з підприємствами й організаціями інформаційних центрів 3 визначення потреб у працівниках для кожної галузі.

Кожна із зазначених характеристик ефективного соціального партнерства потребує відповідних умов.

Розглянемо їх.

1. Забезпечення високої якості підготовки фахівців за професією, спеціальністю - одна з умов забезпечення соціального партнерства в Україні.

Щодо контролю якості професійної (професійно-технічної) освіти (далі П(ПТ)О) в Україні, то його здійснюють органи управління освіти на місцевому рівні з використанням матеріалів Центру освітнього моніторингу [8].

Як свідчать офіційні статистичні дані Центру освітнього моніторингу, для системи П(ПТ)О двоє з трьох роботодавців вважають рівень підготовки кваліфікованих робітників у державних закладах П(ПТ)О недостатнім, таким, що не повністю відповідає потребам виробництва. Результати анкетування свідчать про те, що роботодавці надають перевагу підготовці кваліфікованих робітників у власних навчальних центрах [7].

Позитивним для України в даному напрямі є досвід провідних європейських держав. Наприклад, у Фінляндії цим питанням опікуються на регіональному рівні органи управління освітою, науково-дослідні установи та навчальні заклади у співпраці із соціальними партнерами. Моніторинг дозволяє визначати стан відповідності підготовки робітничих кадрів потребам ринку праці, що, у свою чергу, сприяє реальному плануванню обсягів та напрямів навчання [3].

В інших європейських країнах питання щодо підготовки робітників вирішено за рахунок визначених законодавством обов'язкових відрахувань 3 доходів підприємств. Наприклад, у Франції підприємства виділяють на це майже 18\% від суми своїх доходів, в Австрії- 22\%, у Німеччині функціонує система двоканального фінансування, яка передбачає 55\% витрат з державного фінансування та 45\% приватних надходжень [3].

Як зазначають вітчизняні експерти, досвід країн ЄС свідчить, що для досягнення результативності й ефективності системи П(ПТ)О необхідно проводити значну кількість досліджень стану та змін, що відбуваються на ринку праці для визначення переліку професій, які користуватимуться попитом роботодавців, а також професій, з яких кадрів підготовлено більше, ніж реально потребує ринок праці. Тому для України цей досвід є корисним і потребує узагальнення, особливо в умовах децентралізації фінансування П(ПТ)О, що вимагає на даний час: розробки механізму багатоканального та різнорівневого фінансування ЗП(ПТ)О; створення нової методики розрахунку вартості підготовки кваліфікованих робітників з урахуванням складності, наукоємності та матеріалоємності професій; посилення уваги науковців до проведення маркетингових досліджень для вивчення потреб різних галузей економіки у кваліфікованих робітничих кадрах; упровадження у професійну підготовку фахівців у закладах П(ПТ)О сучасних електронних навчальних ресурсів та дистанційного професійного навчання.

Тому, для забезпечення соціального партнерства в Україні за напрямом "Якість підготовки фахівців" доцільним вважаємо: вдосконалення законодавства, зокрема у сфері освіти, та розробку плану дій щодо реалізації чинного освітнього законодавства (правова умова); підвищення уваги Центру освітнього моніторингу до організації і проведення внутрішнього аудиту діяльності закладів освіти (організаційна умова); збільшення цільового фінансування на проведення моніторингових досліджень станута змін у закладах освіти (фінансова умова); розробку освітніх і професійних стандартів нового покоління для всіх галузей діяльності (кадрова/ресурсна умова).

2. Запровадження нових професій, спеціальностей за запитом суспільства $\epsilon$ перспективним завданням для системи П(ПТ)О України. Експертами визначено, що в найближчі 5-10 років найперспективнішими будуть такі професії, як [12]: продавець, IT-фахівець, інженер 3 автоматизації виробництва, інженер комунального обслуговування, агроінженер, технолог з виробництва і переробки харчової продукції, енергетик, ветеринар, фармаколог, інженер зв'язку, генетик, біохімік, робототехнік, нано-інженер.
При цьому, як зазначають українські експерти [9]:

- навчальні заклади продовжують готувати економістів та юристів замість електрозварювальників та слюсарів, продавців, технологів;

- безробіття все ще залишається високим, а попит на спеціалістів не відповідає пропозиції;

- великою залишається частка українців, які працюють "у тіні".

Подальший розвиток регіональної системи П(ПТ)О та підготовки кваліфікованих робітників пов'язаний з оновленням законодавчої бази, визначенням механізмів фінансування галузі, запровадженням державно-приватного партнерства, унормуванням взаємної відповідальності провайдерів і замовників освітніх послуг у забезпеченні професійної підготовки кадрів, утворенням у регіонах дієвих міжгалузевих рад з професійної освіти, розвитком договірних відносин між навчальними закладами та організаціями різних організаційно-правових форм із залученням матеріальнотехнічного і фінансового ресурсу замовника, формуванням реального регіонального замовлення на підготовку робітничих кадрів на середньострокову та довгострокову перспективу за професіями і кваліфікаціями.

Як зазначають українські експерти, основними негативами залишається невідповідність попиту і пропозиції робочої сили, нестача якісних робочих місць 3 гідними умовами та оплатою праці на ринку праці, недостатня кількість робочих місць у селі, постійний попит на працівників галузей виробництва і сфери послуг, низька якість робочої сили, потреба в робітниках найпростіших професій, структурний дефіцит кадрів у деяких галузях регіональної економіки.

Таким чином, умовами забезпечення соціального партнерства для інструменту "Нові професії, спеціальності за запитом суспільства" є вдосконалення чинного законодавства 3 освіти (правові умови); створення регіональних систем П(ПТ)О та підготовки кваліфікованих робітників, налагодження системи збирання даних про ринок праці (організаційні умови); визначення механізмів фінансування підготовки кваліфікованих працівників галузі (фінансові умови); залучення маркетологів до регіональних систем П(ПТ)О та підготовки кваліфікованих робітників для визначення потреб галузі (кадрові умови).

3. В Україні досить активно застосовуються контрактні форми реалізації партнерських взаємин у фінансуванні підприємцями матеріально-технічної бази 
закладів освіти, однак недостатньо, на наш погляд, фінансувати освітні програми з підготовки фахівців на основі спільно створених з підприємцями кваліфікаційних вимог. Тобто у приватних закладах освіти освітні програми з підготовки фахівців створюються у співпраці 3 підприємцями і підтримуються ними. Стосовно інших закладів освіти, то така взаємодія не є системною і більшість освітніх програм лише формально погоджуються з роботодавцями.

Зазначимо, що важливою фінансовою підтримкою є діяльність: посольств провідних держав $\mathrm{CC}$, акредитованих в Україні, які надають іiі окремим мікропроектам; органів місцевого самоврядування, що активно підтримують соціальні підприємницькі ініціативи; міжнародних громадських організацій. Також розвивається політика стипендіальних фондів.

Незважаючи на розвиток політики стипендіального фонду, в Україні фінансова підтримка розробки нових освітніх програм не стала пріоритетною. Тому для забезпечення соціального партнерства в Україні за напрямом "Контрактна форма реалізації партнерських відносин" бажано, на наш погляд, посилити нове законодавство з освіти щодо активізації запровадження контрактної форми реалізації партнерських взаємин (нормативно-правова умова), створити умови для збільшення кількості суб'єктів підтримки політики стипендіальних фондів (політична умова), забезпечити функціонування Національного фонду досліджень (організаційна умова), удосконалити фінансування освітніх програм з підготовки фахівців на основі спільно створених $з$ підприємцями кваліфікаційних вимог (фінансова умова).

4. Удосконалення процедури проходження виробничої та переддипломної практики здобувачів освіти на підприємствах та організаціях потребує врегулювання.

Згідно з чинним Законом України "Про освіту" (Відомості Верховної Ради (BВP), 2017, № 38-39, ст. 380) [5], діє стаття 9 "Форми здобуття освіти", якою передбачена серед інших і нова формамережева, під якою розуміють спосіб організації навчання здобувачів освіти, завдяки якому оволодіння освітньою програмою відбувається за участю різних суб'єктів освітньої діяльності, що взаємодіють між собою на договірних засадах.

У зв'язку з цим особливої уваги 3 боку суб'єктів освітньої діяльності у частині забезпечення здобувачів освіти виробничою практикою потребують такі статті чинного закону, як ст. 15
"П(ПТ)О", ст. 16 "Фахова передвища освіта", ст. 17 "Вища освіта", ст. 18 "Освіта дорослих".

Аналізуючи зазначені статті чинного Закону України "Про освіту", акцентуємо увагу на тому, що в кожному закладі П(ПТ)О фахової передвищої освіти, вищої освіти, освіти дорослих виникають додаткові суб'єкти освітньої діяльності, окрім держави та штатних працівників. Це: органи місцевого самоврядування, підприємства, установи, організації, окремі фізичні та/або юридичні особи за угодами (ст. 15); навчально-методичні, навчальні, науково-виробничі та інші об'єднання за галузевими або професійними ознаками (ст. 16); наукові, науково-технічні, інноваційні установи (ст. 17); інші працівники закладів післядипломної освіти, які мають ліцензію на освітню діяльність (ст. 18).

Нові підходи до організації освіти, закладенні чинним законом України, передбачають залучення різних суб'єктів освітньої діяльності, що взаємодіють між собою на договірних засадах і змінюють при цьому статус наглядової (піклувальної) ради закладу освіти, який визначений ст. 29 цього закону і яким встановлено, що "наглядова (піклувальна) рада має право: брати участь у визначенні стратегії розвитку закладу освіти та контролювати її виконання; сприяти залученню додаткових джерел фінансування; аналізувати та оцінювати діяльність закладу освіти та його керівника; контролювати виконання кошторису та/або бюджету закладу освіти і вносити відповідні рекомендації та пропозиції, що $\epsilon$ обов'язковими для розгляду керівником закладу освіти; вносити засновнику закладу освіти подання про заохочення або відкликання керівника закладу освіти $з$ підстав, визначених законом; здійснювати інші права, визначені спеціальними законами та/або установчими документами закладу освіти".

Для більшості закладів освіти України такий процес залучення різних суб'єктів освітньої діяльності лише розпочався, хоча зроблено вже немало. Як зазначає Міністр освіти і науки України Лілія Гриневич, говорячи про виконання Плану роботи Міністерства освіти і науки України (далі МОН України) за 2017 рік [5]:

- "державні освітні стандарти з конкретних професій погоджено роботодавців України" (п. 60 звіту) на виконання Закону України "Про організації роботодавців, їх об'єднання, права i гарантіїї діяльності";

- "забезпечено: функціонування у закладах вищої освіти підрозділів спри- яння працевлаштуванню студентів та випускників; соціальне партнерство МОН України з Асоціаціями роботодавців у сфері професійної підготовки та галузевих зв'язків з роботодавцями; функціонування системи зворотного зв'язку між роботодавцями і закладами вищої освіти для отримання об'єктивної оцінки якості професійної підготовки студентів" (п. 62 звіту) на виконання Закону України "Про внесення змін до Закону України "Про вищу освіту" щодо забезпечення працевлаштування випускників" № 1662-УШ від 01.10.2016 p.;

- видано наказ МОН України від 14.07.2017 p. № 1034 "Про призначення стипендій Президента України переможцям Всеукраїнських конкурсів фахової майстерності серед учнів закладів П(ПТ)О у 2017 році" (п. 76 звіту) на виконання Положення про стипендії Президента України для призерів і учасників всеукраїнських конкурсів фахової майстерності серед учнів закладів П(ПТ)О" та ін.

Для забезпечення соціального партнерства за напрямом "Вдосконалення процедури проходження виробничої та переддипломної практики здобувачів освіти на підприємствах й організаціях" необхідно створити додаткові умови (див. табл. 1).

5. Створення спільних інформаційних центрів з визначення потреби у працівниках для кожної галузі вимагає розвитку українського сегменту світової мережі Інтернет. Для цього, як стверджують експерти, необхідно спрямувати економіку на: підготовку високоякісних IT-фахівців та їх збереження для України; збільшення пропускної спроможності каналів мережі Інтернет; зменшення вартості оренди каналів мережі Інтернет; збільшення фінансових можливостей операторів каналів мережі Інтернет, що надають послуги; підвищення платоспроможності користувачів мережі Інтернет; залучення іноземних і вітчизняних інвестицій у проекти інформатизації.

Вирішення цих та інших завдань інформатизації української економіки сприятиме запровадженню спільних інформаційних центрів з визначення потреби у працівниках для кожної галузі, що дозволить:

а) підприємствам та організаціям галузі акумулювати в одному місці інформацію про вакансії та пропозиції;

б) закладам освіти - "отримати інформацію про кадрові потреби підприємств та організацій; аналізувати кон'юнктуру ринку праці молодих фахівців 3 метою вдосконалення змісту навчальних програм; здійснювати цільову підготовку 
Умови забезпечення соціального партнерства за напрямом «Якість підготовки фахівців за профілем спеціальності» в Україні

\begin{tabular}{|c|c|c|}
\hline \multirow{2}{*}{$\begin{array}{c}\text { Напрям соціального } \\
\text { партнерства }\end{array}$} & \multicolumn{2}{|r|}{ Умова забезпечення } \\
\hline & Вид умови & Шляхи реалізації \\
\hline \multirow{4}{*}{$\begin{array}{l}\text { Удосконалення } \\
\text { процедури проходження } \\
\text { виробничої та } \\
\text { переддипломної } \\
\text { практики здобувачами } \\
\text { освіти на підприємствах } \\
\text { та організаціях }\end{array}$} & Правова & $\begin{array}{l}\text { Законодавчо введено нові завдання для закладів освіти } \\
\text { щодо залучення додаткових суб'єктів освітньої діяльності } \\
\text { до освітнього процесу }\end{array}$ \\
\hline & Організаційна & $\begin{array}{l}\text { Потребує створення на підприємствах та в організаціях } \\
\text { служб забезпечення проходження виробничої } \\
\text { переддипломної практики здобувачів освіти }\end{array}$ \\
\hline & Фінансова & $\begin{array}{lccc}\text { Потребує } & \text { унормування } & \text { процедури } & \text { проходження } \\
\text { виробничої } & \text { та переддипломної практики } \\
\text { праці } & & & \end{array}$ \\
\hline & Кадрова & $\begin{array}{l}\text { Потребує спеціальної підготовки менторів на } \\
\text { підприємствах та в організаціях для забезпечення } \\
\text { виробничої і переддипломної практики здобувачів освіти }\end{array}$ \\
\hline
\end{tabular}

фахівців; розміщувати портфоліо студентів-випускників; вести моніторинг працевлаштування випускників, якості їх освіти, виробничих потреб роботодавців у якості освітніх послуг; здійснювати перепідготовку та підвищення кваліфікації співробітників підприємств, виходячи $з$ потреб та можливостей за спільними навчальними програми; розробляти довгострокові програми підготовки фахівців для підприємств профільної галузі" [11].

Усе ж в Україні поступово формується інфраструктура інформаційного суспільства.

Забезпечення соціального партнерства за напрямом "Інформатизація економіки" якнайбільше серед усіх інших потребує створення правових, організаційних, фінансових та кадрових умов (див. табл. 2).

Висновки та перспективи подальших досліджень. Отже в Україні створена лише частина умов для асоціативної роботи різних організацій i підприємств у сфері освіти і науки, а соціальний діалог ще не став соціальною інноваційною технологією, інструментом забезпечення стійкої соціальної динаміки в забезпеченні якості освіти. Тому для кожного із зазначених інструментів соціального партнерства (якість підготовки фахівців, нові професії, спеціальності за запитом суспільства, контрактна форма реалізації партнерських взаємин, практика на підприємствах та організаціях, інформатизація економіки) існує необхідність у формуванні та забезпеченні додаткових умов, а саме:

• політичних - збільшення фінансування на інформатизацію економіки та на проведення моніторингових досліджень стану і змін у закладах освіти;

- правових - прийняття законів України "Про П(ПТ)О", "Про освіту дорослих"; удосконалення фінансування освітніх програм з підготовки фахівців на основі спільно створених з підприємцями кваліфікаційних вимог; унормування оплати праці слухачів, що проходять виробничу практику;

- організаційних - створення на підприємствах та організаціях служб забезпечення проходження виробничої i переддипломної практики здобувачів освіти; створення спільних інформаційних центрів з визначення потреби у працівниках для кожної галузі, регіональних систем П(ПТ)О та підготовки кваліфікованих робітників;

- кадрових - створення і запровадження навчальних програм для спеціальної підготовки менторів; розробка освітніх і професійних стандартів нового покоління для всіх галузей діяльності; удосконалення освітніх програм відповідно до ринкових потреб галузі, що стане основою для наших подальших досліджень.

\section{ЛІТЕРАТУРА}

1. Грішнова О. А. Економіка праці та соціально-трудові відносини: підручник. Київ: Знання, 2004. 535 с.

Таблиия 2

Умови забезпечення інструменту соціального партнерства «Інформатизація економіки» та шляхи його реалізації в Україні

\begin{tabular}{|l|c|l|}
\hline \multirow{2}{*}{$\begin{array}{c}\text { Інструменти } \\
\text { соціального } \\
\text { партнерства }\end{array}$} & \multicolumn{3}{|c|}{ Умови забезпечення } \\
\cline { 2 - 4 } $\begin{array}{l}\text { Інформатизація } \\
\text { економіки }\end{array}$ & Правова & \multicolumn{1}{|c|}{ Шапяхи реалізації } \\
\cline { 2 - 4 } & Організаційна & $\begin{array}{l}\text { Потребує створення спільних інформаційних центрів } 3 \\
\text { визначення потреби у працівниках для кожної галузі }\end{array}$ \\
\cline { 2 - 4 } & Фінансова & $\begin{array}{l}\text { Потребує збільшення фінансування на інформатизацію } \\
\text { економіки }\end{array}$ \\
\cline { 2 - 4 } & Кадрова & Потребує удосконалення освітніх програм \\
\hline
\end{tabular}


2. Джига Т. В. Розвиток соціального партнерства в країнах СС та України: порівняльний аналіз: веб-сайт. URL: http://www.nbuv.gov.ua/portal/Soc_Gum/ Gileya/2011 50/Gileya50/P7_doc.pdf

3. Діденко О. Забезпечення якості професійної підготовки кваліфікованих робітників в ринкових умовах: веб-сайт. URL: http://lib.iitta.gov.ua/7779/1/Забезпечення\%20якості\%20професійної\%20підготовки \%20кваліфікованих \%20 робітників \%20в\%20ринкових\%20умовах.pdf

4. Економічна й соціальна рада Французької Республіки - шлях до демократії майбутнього. Соціальний діалог. Міжнародний досвід: офіційний веб-сайт Національної тристоронньої соціально-економічної ради. URL: http:// www.ntser.gov.ua/ua/dialog/ experience.html

5. Звіт про виконання Плану роботи МOН за 2017 рік: веб-сайт. URL: https:/ /mon.gov.ua/storage/app/media/publichnainformatsiya/2018/03/02/2017.pdf

6. Красномовець В. А., Пасєка А. С. Соціальне партнерство в системі соціально-трудових відносин України: особливості формування та перспективи розвитку: веб-сайт. URL: file:///C:/Users/Lida/ Desktop/сергєєва\%2 03/умови\%20соцпартнерство/stvttp_2013_2_24.pdf

7. Моніторинг стану професійно-технічної освіти та альтернативні пропозиції щодо ії модернізації / За матеріалами ГО "Центр 10 освітнього моніторингу" в рамках проекту "Створення організаційної платформи громадського центру аналізу освітньої політики": веб-сайт. URL: http://centromonitor.com.ua

8. Про Національну стратегію розвитку освіти в Україні на період до 2021 року . Указ Президента України від 25.06.13 року № 344/2013: веб-сайт. URL: www. ligazakon. ua

9. Ринок праці-2018. ТОП-20 професій, яких гостро потребує Україна: веб-сайт. URL: https://glavcom.ua/ economics/finances/rinok-praci-2018-top20 -profesiy-yakih-gostro-potrebuje- ukrajina-517151.html

10. Ситник Ю. О. Соціальне партнерство в Україні: особливості становлення і перспективи розвитку. Наукові записки Кіровоградського національного технічного університету. 2009. № 5. С. 8189.

11. Создание единого информационного центра взаимодействия вузов с участниками рынка труда: веб-сайт. URL: http://docplayer.ru/75970143-Sozdanieedinogo-informacionnogo-centravzaimodeystviya-vuzov-s-uchastnikamirynka-truda.html

12. ТОП-20 найперспективніших професій: веб-сайт. URL : https:// life.pravda.com.ua/society/2009/08/28/ 25602/

\section{REFERENCES}

1. Hrishnova O. A. Ekonomika pratsi ta sotsialno-trudovi vidnosyny: Pidruchnyk / O. A. Hrishnova. K.: Znannya, 2004.535 s.

2. Dzhyha T. V. Rozvytok sotsialnoho partnerstva vkrayinakh YES ta Ukrayiny: porivnyalnyy analiz. URL : http:// www.nbuv.gov.ua/ portal/Soc_Gum/ Gileya/2011_50/Gileya50/P7_doc.pdf

3. Didenko O. Zabezpechennya yakosti profesiynoyi pidhotovky kvalifikovanykh robitnykiv v rynkovykh umovakh. URL : http://1ib.iitta.gov.ua/7779/1/ Zabezpechennya\%20yakosti\%

20profesiynoyi \%20pidhotovky\% 20 kvalifikovanykh\%20robitnykiv\% 20v\%20rynkovykh\%20umovakh.pdf

4. Ekonomichna i sotsialna rada Frantsuzkoyi Respubliky - shlyakh do demokratiyi maybutnoho. Sotsialnyy dialoh. Mizhnarodnyy dosvid//Ofitsiynyy veb-sayt Natsionalnoyi trystoronnoyi sotsialno-ekonomichnoyi rady. URL : http://www.ntser.gov.ua/ua/dialog/ experience.html

5. Zvit pro vykonannya Planu roboty MON za 2017 rik. URL : https:// mon.gov.ua/storage/app/media/publichna- informatsiya/2018/03/02/2017.pdf

6. Krasnomovets V. A., Pasyeka A. S. Sotsialne partnerstvo v systemi sotsialnotrudovykh vidnosyn Ukrayiny: osoblyvosti formuvannya ta perspektyvy rozvytku. URL : file://C:/Users/Lida/ Desktop/serhyeyeva\%2 03/ u movy\% 20 sots partnerstvo/ stvttp_2013_2_24.pdf

7. Monitorynh stanu profesiynotekhnichnoyi osvity ta alternatyvni propozytsiyi shchodo yiyi modernizatsiyi / Za materialamy HO "Tsentr 10 osvitnoho monitorynhu" v ramkakh proektu "Stvorennya orhanizatsiynoyi platformy hromadskoho tsentru analizu osvitnoyi polityky". URL : http:// centromonitor.com.ua

8. Pro Natsionalnu stratehiyu rozvytku osvity v Ukrayini na period do 2021 roku . Ukaz Prezydenta Ukrayiny vid 25.06.13 roku № 344/2013. URL : www. ligazakon. ua

9. Rynok pratsi-2018. TOP-20 profesiy, yakykh hostro potrebuye Ukrayina. URL : https://glavcom.ua/ economics/finances/rinok-praci-2018-top20 -profesiy-yakih-gostro-potrebujeukrajina-517151.html

10. Sytnyk YU. O. Sotsialne partnerstvo v Ukrayini: osoblyvosti stanovlennya i perspektyvy rozvytku [tekst] / YU. O. Sytnyk // Naukovi zapysky Kirovohradskoho natsionalnoho tekhnichnoho universytetu. 2009. № 5. S. 81-89.

11. Sozdaniye yedinogo informatsionnogo tsentra vzaimodeystviya vuzov s uchastnikami rynka truda. URL : http://docplayer.ru/75970143-Sozdanieedinogo-informacionnogo-centravzaimodeystviya-vuzov-s-uchastnikamirynka-truda.html

12. TOP-20 nayperspektyvnishykh profesiy. - URL: https://life.pravda.com.ua/ society/2009/08/28/25602/

Стаття надійшла 10.04.2019 p. 